\title{
Analysis of Capital Market Literacy, Risk Preferences, and Financial Behavior on The Probability of Investment Decisions in The Stock Market
}

\author{
Nivi Hendwiyani and Maria Ulpah \\ \{nivi.hendwiyani@gmail.com,mulpah@ui.ac.id\} \\ Faculty of Economics and Business Universitas Indonesia
}

\begin{abstract}
This research was conducted to analyze capital market literacy, risk preferences, and financial behavior towards the probability of investment decisions in the stock market. The research model uses a questionnaire as a research instrument with a sample of Indonesian citizens living in Indonesia with a minimum age of 18 years. Furthermore, binary logistic regression is applied to find out whether capital market literacy, risk preferences, and financial behavior affect the probability of investors' investment decisions in the stock market. The results showed that capital market literacy and risk preferences significantly influenced the probability of investment decisions. This research is also analyzes whether gender affects capital market literacy and risk preferences. Crosstabulation test results showed that men tend to invest in shares and have higher level of capital market literacy and risk preferences compared to women.
\end{abstract}

Keywords: Capital Market Literacy, Financial Behavior, Investment Decisions, Risk Preferences.

\section{Introduction}

Individuals who make financial decisions, then they are faced with 3 (three) main areas, namely: spending, savings, and investing. Every decision taken by individuals in each of these areas requires good planning. Ideally, an investment requires a sustainable time in order to obtain maximum benefits in the future. Investment is defined as an activity that guarantees capital safety and satisfactory returns [8]. Of course, these investment activities require a thorough analysis that requires adequate knowledge and capabilities.

In Indonesia, the stock market can be used as an investment product choice that can be chosen by the public. However, until now, the participation of Indonesian people in the capital market is still relatively low. Looking the results of a national survey conducted by the Financial Services Authority (OJK) showed that the capital market inclusion index in 2016 was very low at 
only $1.3 \%$ - an increase of $1.2 \%$ from 2013 . This number is very far compared to inclusions in other financial sector, especially the banking sector which reached $63.6 \%$ in 2016.

The low participation in investing in the capital market is thought to be due to the low understanding of products, capital market literacy, and individual risk preferences. Financial literacy in the capital market sector has the lowest percentage among other financial services sectors, namely only $4.4 \%$ in 2016 an increase of $0.6 \%$ from 2013. Risk preference is also thought to be one of the factors of the low level of capital market inclusion. In 2015, Indonesia Stock Exhange (IDX) in collaboration with Nielsen conducted a survey measuring potential investors in 9 major cities, namely Jakarta, Bandung, Surabaya, Denpasar, Makassar, Balikpapan, Medan, Palembang and Semarang. The survey results obtained data that most people assume that investing in the stock market is very risky. Whereas, in general, people are risk averse. Therefore, people tend not to invest in the stock market.

Looking at the percentages of the survey results above that showed the low participation in investing in the capital market and looking at investor data taken from the IDX, the authors are interested in examining the relationship of the level of Indonesian people's capital market literacy to the probability of investment decisions on the stock market. Research examining factors that can influence investment decisions has been conducted by previous researchers. van Rooij, M. (2011) [17] looks at how financial literacy influences the choice of investors to invest. The results of the study are that investors will invest in stocks if they have high financial literacy.

In investing, investors are also faced with risks that may occur. Investment risk is defined as an uncertainty in investment. Like financial literacy and capital markets, each individual has different risk preferences. Cooper, W. W. (2014) [4] conducted research related to investors' risk profiles in influencing their investment decision making. Cooper, W. W., et al (2014) also looked at demographic relationships such as age, gender, relationship status, financial literacy and income to investor risk tolerance. Aren, S (2016) [3] analyzes that financial literacy and risk perception are important in affecting investor preferences in investing.

Based on previous studies, the authors will examine capital market literacy, risk preferences, and financial behavior towards the probability of a stock investment decision. The authors are examine the level of capital market literacy, level of risk preference, and financial behavior towards the probability of investment decision in stock market. In addition, the authors will also look at whether investor demographic such as gender has a role in investment decisions. This research are aim to look whether market literacy 
has an influence on investment product selection decisions; to look whether risk tolerance affects investment decisions in the capital market; and to look whether a person's financial behavior affects his investment decisions in the capital market.

The difference between this study and previous research lies in the research data, this study uses a sample of Indonesian citizens with a minimum age of 18 years. Then, this research focuses directly on how level of capital market literacy, level of risk preference, and financial behavior influence the probability of a stock investment decision in Indonesia. The authors chose to examine investment decisions in the stock market to see the direct involvement of investors in managing their portfolios. This is different if investors choose to invest in mutual funds where the investment portfolio is managed by the investment manager. Similar studies regarding the probability of respondents investing in stock market have not been found yet in Indonesia.

\section{Literature}

Financial literacy is measuring how far people understand financial concepts, have the ability and confidence to manage their finances through appropriate short-term decision making, and also healthy long-term planning [14]. Financial inclusion, defined as a measurement of the ease of access and use of financial services, is an important objective of the economy in particular, financial development [9]. Grohmann [9] also explained that higher financial literacy would be systematically linked to better financial inclusion.

In Indonesia, the Government launched the national strategy for Inclusive Financial Literacy (SNLKI) in 2016 which was stated through Presidential Regulation No. 82 of 2016 [12]. The SNLKI aims to improve and expand Indonesian people's access to financial services. In SNLKI, the level of financial literacy is divided into 4 (four) level: not literate, less literate, sufficient literate, and well literate. The survey shows the percentage of financial literacy in Indonesia is relatively low. The national average index of financial literacy was only $29.7 \%$ in 2016 . To encourage the SNLKI, the government together with regulators try to increase financial literacy by conducting financial education. Financial education is believed to increase financial literacy, motivate financial behavior so that it can improve the financial welfare of the people [11].

Cordell, D. M. [5] explained risk tolerance into a framework consisting of 4 (four) components: Propensity, Attitude, Capacity, and Knowledge which are abbreviated as RiskPACK. RiskPACK is useful for financial planners in 
analyzing the level of risk tolerance. Propensity is defined as the tendency of investors' decisions in a financial situation, whether consciously or not. This component is measured by looking at an investor's financial decisions taken in the past (historical). Attitude refers to an investor's willingness to assume risk. Capacity refers to how much an investor is willing to take on the risk. Knowledge refers to investors' understanding of risks and risk-return tradeoffs. The relationship between propensity, attitude, capacity, and knowledge in risk refers to the following figure 1.

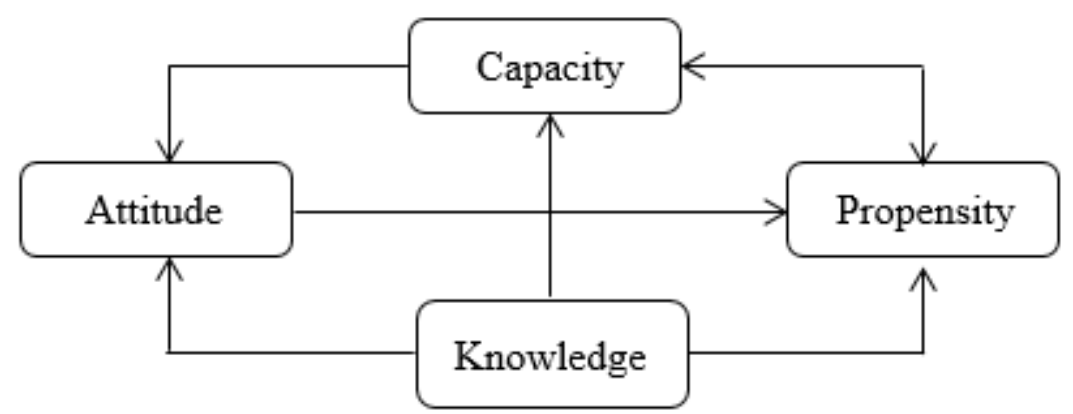

Fig. 1. RISKPACK by Cordell, D. M. (2001)

However, Cordell's RiskPACK indicator has weaknesses. This indicator cannot be used in the long term because people's risk tolerance may change when they increase knowledge and experience in the world of finance. Therefore, the level of validity of this indicator is only accurate when financial planners or researchers who examine the risk tolerance level of investors conduct such research. This study will examine the risk tolerance of respondents with data collection limits within 20 days of distributing questionnaires.

Behavioral finance according to Ritter (2003) [15] is that there is the influence of psychological aspect that influences decision making and also limits to arbitrage where investors take advantage of inefficient markets. People will make systematic mistakes when they are thinking: overconfidence, too much trust in events or experiences that have just happened, and individual preferences that will distort bias in decision making. The biases will lead to an error in processing of available information. The psychological aspect has introduced various behavioral biases that can influence financial decision making.

Kahneman (1979) [10] does not believe that agents of economic theory are rational. Kahneman criticizes expected utility theory and introduces prospect theory. In this theory, the utility of the results is weighed based on their 
probabilities. Kahneman further explained that people's preferences systematically violated this principle. People will ignore the results obtained based only on probability, compared with definite results.

Indonesia has a variety of financial products that people could choose. There are at least 6 (six) financial services sectors: banking, capital markets, pension funds, insurance, pawnshops, and financing institutions [12]. Within these sectors, various financial products are available for people to invest. Each product requires proper management in order to get the desired returns. However, public knowledge about financial services makes it difficult for them to choose investment products. The results of the OJK national survey in 2016 showed that the public had very good knowledge of the banking sector. However, when viewed from the level of public knowledge about the capital market sector, the survey results only showed $15.7 \%$.

\section{Research Methodology}

The purpose of this study is to examine capital market literacy, risk preferences, and financial behavior of investors to the probability of investment decision making in the stock market. The authors also want to see the effect of demographic aspect such as gender on capital market literacy and risk preferences. The difference from previous studies is that the final results of this study look at the probability level of respondents who invest in shares. Similar studies regarding the probability of respondents investing in shares have not been found in Indonesia. The research model in this study is shown in figure 2 as follows:

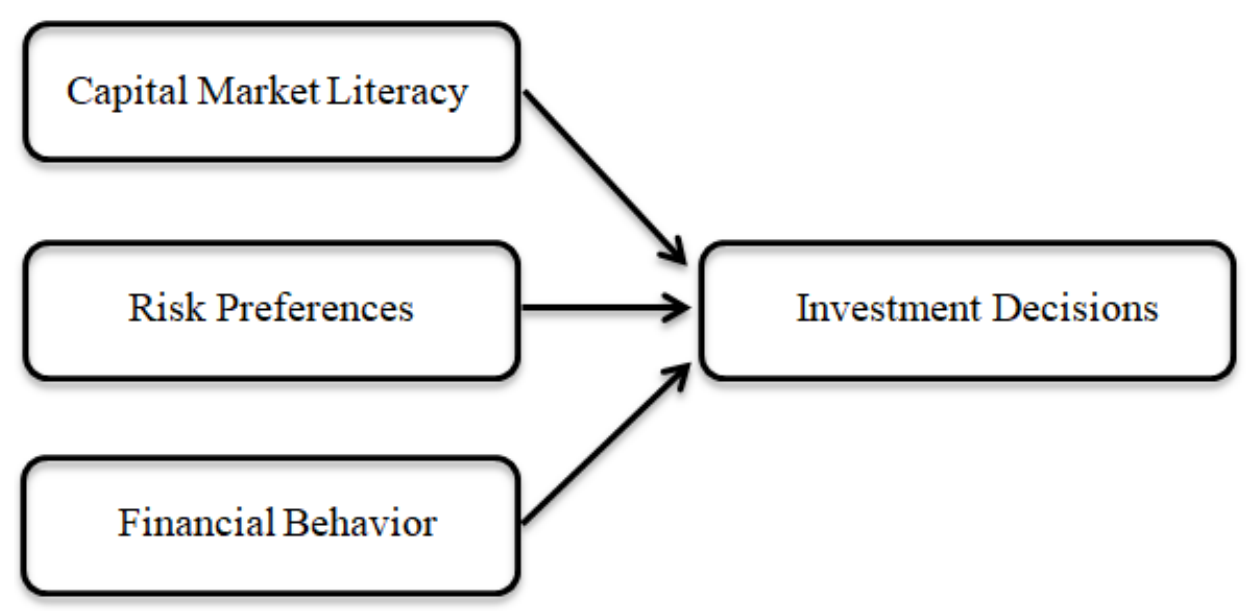


Fig. 2. Research Model

H1 : Capital market literacy affects the probability of a stock investment decision

H2 : Risk preferences affect the probability of a stock investment decision

H3 : Financial behavior affects the probability of stock investment decisions

Primary data is used by the authors through the distribution of a questionnaire. Questionnaires are distributed online, through the Google form. In compiling the questionnaire, the authors adopted a questionnaire from previous studies with several adjustments. To measure the level of capital market literacy, the authors adopted a questionnaire from the research of van Rooij, M. (2011). To measure the level of risk preference, the authors adopted a questionnaire from Cooper, W. W. (2014) research. To measure attitudes of financial behavior, the authors adopted a questionnaire compiled by the OECD (2018) [13]. Aspect of investment decision is prepared based on simple questions regarding the use of financial / investment products. Table 1. is the summary of the adoption of the previous research questionnaire:

Table 1. Questionnaire

\begin{tabular}{|c|c|c|c|}
\hline Variable & Source & Information & Total \\
\hline $\begin{array}{c}\text { Capital Market } \\
\text { Literacy }\end{array}$ & $\begin{array}{c}\text { van Rooij, M. } \\
(2011)\end{array}$ & $\begin{array}{c}\text { Adopt the question of advance } \\
\text { financial literacy }\end{array}$ & 8 \\
\hline Risk Preferences & $\begin{array}{c}\text { Cooper, W. W. } \\
(2014)\end{array}$ & Adopt 2 from 4 aspects & $1+13$ \\
\hline Financial Behavior & OECD (2018) & $\begin{array}{c}\text { Adopt 1 group questions of attitude } \\
\text { and behavior }\end{array}$ & 11 \\
\hline $\begin{array}{c}\text { Investment } \\
\text { Decisions }\end{array}$ & & & 1 \\
\hline
\end{tabular}

Questionnaires that have been made are then distributed online for 20 days, starting from March 13, 2020 to April 1, 2020. The criteria for the sample object of this study are:

1. Indonesian Citizen;

2. Settling in Indonesia;

3. Minimum age is 18 (eighteen) years old

To describe the relationship between the independent variables of capital market literacy, risk preferences, and financial behavior with the dependent 
variable investment decisions, the authors conducted a predictive logistic regression test, also known as the logit model. According to Dahlan (2019) [6], logistic regression is used when the dependent variable is a dichotomous variable which has only 2 probabilities. The dependent variable in this study is the dichotomous variable between the probability of investing in stock and the probability of not investing in stock. Before carrying out logistic regression, it is necessary to test the multicollinearity assumption, which is to test the relationship between independent variables. In the logistic regression test, the independent variable must not experience multicollinearity disorder. This logit model equation is stated by:

$$
y=a+\beta_{1} X_{1}+\cdots+\beta^{i} X^{i}
$$

\section{Results}

Data of valid respondents meeting the criteria was 372 people. From 372 data that met the criteria, it was found that 214 people $(57.5 \%)$ were male respondents while female respondents were 158 people $(42.5 \%)$. The age of respondents is at most $21-30$ years old, that is 218 people $(58.6 \%)$ while the fewest are respondents over the age of 51 years, 4 people (1.1\%). Java became the island most inhabited by respondents, namely as many as 303 people $(81.5 \%)$ and the least originated from the Maluku Islands as many as 1 person $(0.3 \%)$.

Table 2 . shows that the probability that respondents invest stock is $62.1 \%$. The probability of men investing in stock is $69.2 \%$ and the probability of women investing in stock is $52.5 \%$.

Table 2. Investment Choices

\begin{tabular}{|c|c|c|c|}
\hline Investment Choices & Men & Women & Total \\
\hline Investing in Stock & 148 & 83 & 231 \\
\hline Not Investing in Stock & 66 & 75 & 141 \\
\hline Total & $\mathbf{2 1 4}$ & $\mathbf{1 5 8}$ & $\mathbf{3 7 2}$ \\
\hline
\end{tabular}

After scoring the level of capital market literacy, the following data are obtained:

Tabel 3. The Level Of Capital Market Literacy 


\begin{tabular}{|c|c|c|}
\hline Category & Total Respondent & Percentage \\
\hline Not literate & 27 & $7,3 \%$ \\
\hline Less literate & 71 & $19,2 \%$ \\
\hline Sufficient literate & 126 & $33,9 \%$ \\
\hline Well literate & 148 & $39,8 \%$ \\
\hline Total & 372 & $100 \%$ \\
\hline
\end{tabular}

Based on the table 3, the respondent's capital market literacy in this study is at the most well literate by 148 people $(39.8 \%)$ and the least is not literate by 27 people $(7.3 \%)$. However, only 39 out of 372 respondents received a perfect score of $10.5 \%$.

In this study, the binary dependent variable is investment decisions in the stock market. While the independent variables are capital market literacy, risk preferences, and financial behavior. The authors encode the investment decision variable, namely (0) if the respondent does not invest in the stock market, and (1) if the respondent invests in the stock market. The loglikelihood test is to assess the feasibility of the model. The hypothesis for assessing eligibility is:

H0 : The research model is fit with the data

H1 : The research model does not fit the data

In the results of block 1 in table 4., the highest -2 Log Likelihood value is 382,004 and the lowest is 372,529 . This value is compared with the ChiSquare table value (N-1-number of independent variables $=372-1-3=368$ ). Chi-Square Table with a probability of 0.05 is 413.732 . From this value, it can be concluded that the value of $-2 \log$ Likelihood $(382,004)<$ Chi-Square Table $(413,732)$. Thus, this study accepts H0, meaning that the model by including capital market literacy variables, risk preferences, and financial behavior as an independent variable is fit with data and can be used.

Table 4. Block: 1 Method $=$ Enter Iteration History $\mathbf{a}, \mathbf{b}, \mathbf{c}, \mathbf{d}$

\begin{tabular}{|c|c|c|c|c|c|c|}
\hline \multirow[t]{2}{*}{ Iteration } & & \multirow[t]{2}{*}{-2 Log likelihood } & \multicolumn{4}{|c|}{ Coefficients } \\
\hline & & & Constant & $\begin{array}{c}\text { Capital Market } \\
\text { Literacy }\end{array}$ & Risk Preferences & Finansial Behavior \\
\hline \multirow{5}{*}{ Step 1} & 1 & 382.004 & -5.383 & 1.892 & 1.312 & .197 \\
\hline & 2 & 372.849 & -7.383 & 2.361 & 1.844 & .274 \\
\hline & 3 & 372.530 & -7.855 & 2.453 & 1.971 & .294 \\
\hline & 4 & 372.529 & -7.876 & 2.457 & 1.977 & .295 \\
\hline & 5 & 372.529 & -7.876 & 2.457 & 1.977 & .295 \\
\hline
\end{tabular}

b. Constant is included in the model. 
c. Initial -2 Log Likelihood: 493.710

d. Estimation terminated at iteration number 5 because parameter estimates changed by less than .001 .

In addition to comparing the Log Likelihood value of 2, the results of the Hosmer and Lemeshow Test can also be used to test eligibility. The Hosmer and Lemeshow Test is also known as the Goodness of Fit Test. According to Ghozali (2011), if the significance value is $\leq 0.05$, then $\mathrm{H} 0$ is rejected. This means that the model is not fit because there is a significant difference between the model and its observation value. This study accepts H0, meaning that this regression model is fit. Sig. From this test the results showed 0.928> 0.05. The following table 5 are the results of the Hosmer and Lemeshow Test of this study:

Table 5. Hasil Hosmer and Lemeshow Test

\begin{tabular}{|l|r|r|r|}
\hline \multicolumn{4}{|c|}{ Hosmer and Lemeshow Test } \\
\hline Step & Chi-square & df & \multicolumn{1}{c|}{ Sig. } \\
\hline 1 & 3.093 & & 8 \\
\hline
\end{tabular}

The logit test results show that the independent variable capital market literacy and risk preferences have a Sig. 0,000<0.05 each. Capital market literacy coefficient has a value of 2.457 , risk preference has a coefficient of 1.977, while financial behavior has a coefficient of 0.295 . Therefore, the regression equation of this study is:

$$
y=a+\beta_{1} X_{1}+\cdots+\beta^{\mathrm{i}} X^{\mathrm{i}}
$$

$\mathrm{a}=$ konstanta

$\mathrm{X}=$ independen variable

$\beta=$ coefficient of the independent variable

$$
\begin{aligned}
y=-7,7876+ & 2,457(\text { capital markte literacy })+1,977(\text { risk preferences }) \\
& +0,295(\text { financial behavior })
\end{aligned}
$$

How far of the effect of the independent variable on the independent variable is shown from the value of EXP (B) or often also referred to as Odds Ratio (OR). Dahlan (2019) [6] explains that OR is the odds comparison of the object of comparison. In this study, because the independent variables are 
numeric, the OR compares the value of a variable with the value below it. Capital market literacy and risk preferences have positive OR values, namely 11.673 and 7.221, respectively. Then, the value of the confidence interval from the capital market literacy OR and risk preferences are between 3,76036,237 and 4,129-12,626, respectively. In this interval there is no value of 1 in between. Therefore, it means that there is an influence or relationship between the independent variables on the dependent variable. So it can be interpreted that for one level of capital market literacy, the possibility of investing in shares is 11,673 times compared to the level below it. Likewise with OR on risk preferences. At a level of risk preference, the likelihood of investing shares will be 7,221 times compared to the levels below it. It can be concluded again that this research rejects $\mathrm{H} 0$, which means that capital market literacy and risk preferences each have a significant influence on investment decisions in the stock market.

The independent variable of financial behavior has a value of Sig. $0.382>$ 0.05 which means that it does not have a significant influence on investment decisions in the stock market. The OR value on the financial behavior variable is 1.344 but, at the OR confidence interval, there is a value of 1 at the interval. So it can be concluded that the financial behavior variable has no influence on investment decisions in the stock market.

Simultaneously, the test results show that capital market literacy, risk preferences, and financial behavior influence the investment decisions. This is evidenced by the significance data of $0,000<0.05$ and has a positive ChiSquare value of 121.181 .

In research with predictive logistic regression, to see the ability of independent variables to influence the probability of the dependent variable, the Nagelkerke R Square value is used. Nagelkerke R Square test results are shown in the table 6 :

Table 6. Cox \& Snell R Square and Nagelkerke R Square Test Results Model Summary

\begin{tabular}{|l|r|r|r|}
\hline Step & $\begin{array}{c}-2 \text { Log } \\
\text { likelihood }\end{array}$ & $\begin{array}{c}\text { Cox \& Snell R } \\
\text { Square }\end{array}$ & $\begin{array}{l}\text { Nagelkerke R } \\
\text { Square }\end{array}$ \\
\hline 1 & $372.529^{\mathrm{a}}$ & .278 & .378 \\
\hline
\end{tabular}

a. Estimation terminated at iteration number 5 because parameter estimates changed by less than .001 .

Nagelkerke R Square value in table 6. above indicates that capital market literacy, risk preferences, and financial behavior influence the decision to invest in the stock market by $37.8 \%$. 


\section{Discussion}

In this study, in measuring the level of financial literacy, the authors adopted 1 (one) out of 2 (two) sets of financial literacy questions formed by van Rooij (2011). 1 (one) set of questions the authors adopts are questions regarding advanced financial literacy - in this case specifically related to the capital market. This was done by the authors with the consideration focusing on stock investment decisions. In distributing the research questionnaire, the authors were also helped by influencer media about the capital market, the Instagram account @ngetisaham. So the authors assume that the respondents more or less already know the capital market products. The results of collecting and processing research data, the following results are obtained shown in table 7.:

Table 7. Results of Statistical Tests on Investment Decisions in the Capital Market

\begin{tabular}{|c|c|c|c|c|c|}
\hline Variable & $\begin{array}{c}\text { Pseudo } \\
\mathbf{R}^{\mathbf{2}}\end{array}$ & Sig. & OR & Interval & Results \\
\cline { 1 - 4 } $\begin{array}{c}\text { Capital Market } \\
\text { Literacy }\end{array}$ & \multirow{2}{*}{0.378} & 0.000 & 11,673 & $\begin{array}{c}\text { There is no value } \\
\text { of } 1\end{array}$ & $\begin{array}{c}\text { Have a significant } \\
\text { effect }\end{array}$ \\
\cline { 4 - 6 } & & 0.000 & 7,221 & $\begin{array}{c}\text { There is no value } \\
\text { of } 1\end{array}$ & $\begin{array}{c}\text { Have a significant } \\
\text { effect }\end{array}$ \\
\cline { 3 - 6 } & & 0.382 & 1,344 & $\begin{array}{c}\text { There is a value } \\
\text { of } 1\end{array}$ & $\begin{array}{c}\text { No effect, not } \\
\text { significant }\end{array}$ \\
\hline Financial Behaviorences
\end{tabular}

Initial hypothesis (H1) that capital market literacy has a positive influence on the probability of investment decisions on the capital market can be supported. The results showed that a level of capital market literacy affected 11,673 times significantly compared to 1 level of capital market literacy below it on investment decisions in the stock market. The significance value is 0,000 $<0.05$. The results of the study are in line with previous studies examined by van Rooij (2011). In his research, van Rooij (2011) found that someone who has a low literacy level, tends not to invest in shares.

The level of risk preference also has a significant influence on investment decisions in the stock market. The test results show that the risk preference has a significance value of $0,000<0.05$ with an $\mathrm{OR}$ value of 7.221 . That is, a level of risk preference has an influence on investment decisions on the stock market as much as 7,221 times compared to the lower level of risk preference. Therefore, the $\mathrm{H} 2$ hypothesis that a person's risk preference has an influence on the probability of investment decisions in the stock market can be supported. These results are in line with research Aren, S (2016), that people 
who have high tolerance and risk preferences, will invest in shares. Meanwhile, people who have low tolerance and risk preferences will choose investments in products other than stocks such as deposits, mutual funds, or gold.

Different from the 2 (two) previous independent variables, the financial behavior variable has no influence and is not significant on the probability of investment decisions on the capital market. This is indicated by the significance value greater than 0.05 . The financial behavior variable has a significance value of 0.382 . OR on this variable shows a positive value, but because there is a value of 1 in the OR confidence interval, it is concluded that this variable has no influence on the probability of investment decisions in the capital market. Thus, the initial hypothesis (H3) that financial behavior affects the probability of investment decisions on the stock market cannot be supported. According to Strömbäck (2017) [16], a person's financial behavior is not only influenced by cognitive factors such as financial literacy. A person's financial behavior is also influenced by non-cognitive factors such as self-control, optimism, or deliberation. Self control can be linked as the ability to stop bad habits, resist temptations and overcome impulsive attitudes. When people fail to control themselves, people will act less than optimal. This is the authors' guess so that the financial behavior in this study does not affect financial decisions in investing. In addition to this, the authors also suspect that investment preferences are also one of the factors that cause investment decisions in the stock market are not influenced by financial behavior. Investment preferences referred in here are preferences for investing in products that are familiar. Based on OJK survey data in 2016, Indonesian people's knowledge of capital market institutions is only $15.7 \%$. Furthermore, public confidence in capital market institutions is also very low at only $9 \%$ in 2016. People still favor banking products because they feel more familiar. This is the author's guess why financial behavior does not affect investment decisions in the stock market. Although public financial behavior shows good value, but because of preferences and in-depth considerations as mentioned, financial behavior does not influence investment decisions. These allegations need further observation.

The results of testing between capital market literacy variables, risk preferences, and investor behavior towards investment decision variables in the capital market show that the independent variables simultaneously have a $37.8 \%$ influence on investment decisions on the capital market.

The data shows that the average value of capital market literacy is quite good with a value of 0.71 out of 1 even though only $10.5 \%$ of the total respondents get a perfect score. The results of data processing, the level of 
literacy of respondents classified as well literate is $40.6 \%$. The authors conclude that it can be said to be still relatively low because it does not reach $50 \%$. This is still in line with the national financial literacy survey conducted by OJK which obtained $29.7 \%$ results in 2016 .

Meanwhile, based on the grouping of risk profiles by Grable, JE (1997) [7], the average respondent of this study had an average risk profile with a value of 2.89 out of a maximum value of 5. Data showed that respondents who were classified as no risk and average risk were not invest in shares. The authors were also grouping risk profiles by PT Danareksa (Persero) category which divides the risk profile in Indonesia into low, conservative, moderate, and above average (in Saputra and Anastasia, 2013) [1]. Where the average respondent profile is at moderate level.

Demographic aspect is also examined in this study. The authors conducted a crosstabulation test to compare it. Gender has an influence on a people's risk preferences and participation in investing in the stock market. Data shows that men have a higher risk preference compared to women. As many as $33.3 \%$ of men had a low risk preference level, $41.8 \%$ had a conservative risk preference level, $58.5 \%$ had a moderate level risk, and $75.4 \%$ had a high risk preference level. While $66.7 \%$ of women had a low risk preference level, $58.2 \%$ had a conservative risk preference level, $41.5 \%$ had a moderate level, and $24.6 \%$ had a high risk preference level. Sig. value from this test amounted to $0.001<0.05$. This means that there is a relationship between gender and the level of risk preference. This is in line with research by Almenberg (2015) and Cooper (2014) which revealed that men tend to have a higher risk preference than women [2]. The results also showed that men participated more in investing in the stock market.

Table 8. Results of Risk Preference Crosstabulation \& Investment Decisions

\begin{tabular}{|c|c|c|}
\hline \multirow{2}{*}{ Risk Preference } & \multicolumn{2}{|c|}{ Investment Decisions } \\
\cline { 2 - 3 } & Not Investing in Stock & Investing in Stock \\
\hline Low & $100 \%$ & $0 \%$ \\
\hline Conservatif & $72,2 \%$ & $27,8 \%$ \\
\hline Moderate & $33,6 \%$ & $66,4 \%$ \\
\hline Above & $6,6 \%$ & $93,4 \%$ \\
\hline
\end{tabular}

Table 9. Results of Investment \& Gender Crosstabulation Results

\begin{tabular}{|l|c|c|c|c|}
\hline Investment Decisions & \multirow{2}{*}{$\%$} & \multicolumn{2}{|c|}{ Gender } & \multirow{2}{*}{ Total } \\
\cline { 3 - 4 } & & Men & Women & \\
\hline \multirow{2}{*}{ Not Investing in Stock } & \% within investment decisions & $46,8 \%$ & $53,2 \%$ & $100 \%$ \\
\cline { 2 - 5 } & \% within gender & $30,8 \%$ & $47,5 \%$ & $37,9 \%$ \\
\hline
\end{tabular}




\begin{tabular}{|l|c|c|c|c|}
\hline \multirow{2}{*}{ Investing in Stock } & \% within investment decisions & $64,1 \%$ & $35,9 \%$ & $100 \%$ \\
\cline { 2 - 5 } & $\%$ within gender & $69,2 \%$ & $52,5 \%$ & $62,1 \%$ \\
\hline
\end{tabular}

For the level of capital market literacy, the data shows that people living in DKI Jakarta tend to have higher literacy levels compared to people outside of Jakarta. The data still shows the same results compared to the results of a survey conducted by the OJK in 2016.

\section{Conclusion}

Authors conducted this study with the aim to see how capital market literacy, risk preferences, and investor behavior towards the probability of investment decisions in the capital market. This study obtained as many as 372 valid samples in accordance with predetermined respondent criteria. The time span for distributing the questionnaire was 20 days starting from March 13, 2020 until April 1, 2020. Based on the discussion of the results of the analysis, the conclusions obtained are as follows:

1. Capital market literacy has a positive and significant influence on the probability of investment decisions in the stock market. People with higher literacy levels have a probability of investing shares of 11,673 times with people who have lower literacy levels below.The level of a people's risk preference has a positive and significant effect on the probability of investment decisions in the stock market. People who have high risk preferences tend to invest in stocks compared to people who have low levels of risk preference.

2. The aspect of financial behavior has no influence and is also not significant to the probability of a person's decision to invest in the stock market. 


\section{References}

[1] Anastasia, N., \& Saputra, H. I. Jenis Investasi Berdasarkan Profil Risiko. FINESTA. 2013.

[2] Almenberg, J., \& Dreber, A. Gender, stock market participation and financial literacy. Economics Letters. 2015; 137, 140-142.

[3] Aren, S., \& Zengin, A. N. Influence of financial literacy and risk perception on choice of investment. Procedia - Social and Behavioral Sciences. 2016; 235, 656-663.

[4] Cooper, W. W., Kingyens, A. T., \& Paradi, J. C. Two-stage financial risk tolerance assessment using data envelopment analysis. European Journal of Operational Research. 2014; 233(1), 273280.

[5] Cordell, D. M. RiskPACK: How to evaluate risk tolerance. Journal of Financial Planning. 2001; 14(6), 36-40.

[6] Dahlan, M. Sopiyudin. Analisis Multivariat Regresi Logistik. Jakarta: PT. Epidemiologi Indonesia. 2019.

[7] Grable, J. E. Investor Risk Tolerance: Testing the Efficacy of Demographics as Differentiating and Classifying Factors. Journal of Business and Psychology. 1997.

[8] Graham, B., \& Dodd, D. L. Security analysis: Principles and technique (6th Edition). New York: McGraw-Hill. 2009.

[9] Grohmann, A., Klühs, T., \& Menkhoff, L. Does financial literacy improve financial inclusion? cross country evidence. World Development. 2018; 111, 84-96.

[10] Kahneman, D., \& Tversky, A. Prospect Theory: An Analysis of Decision under Risk. Econometrica. 1979; 47(2), 263-291.

[11] Lusardi, A. \& Mitchell, O. The Economic Importance of Financial Literacy: Theory and Evidence. Journal of Economic Literature. 2014; 52(1), 5-44.

[12] Otoritas Jasa Keuangan. Strategi Nasional Literasi Keuangan Indonesia (Revisit 2017). 2017.

[13] OECD. Oecd/Infe Toolkit For Measuring Financial Literacy And Financial Inclusion. 2018.

[14] Remund, D. Financial Literacy Explicated: The Case for a Clearer Definition in an Increasingly Complex Economy. The Journal of Consumer Affairs. 2010; 44(2), 276-295. The American Council on Consumer Interests.

[15] Ritter, J. R. Behavioral finance. Pacific-Basin Finance Journal. 2003; 11(4), 429-437. 
[16] Strömbäck, C., Lind, T., Skagerlund, K., Västfjäll, D., \& Tinghög, G. Does self-control predict financial behavior and financial well-being? Journal of Behavioral and Experimental Finance. $2017 ; 14,30-38$.

[17] van Rooij, M., Lusardi, A., \& Alessie, R. Financial literacy and stock market participation. Journal of Financial Economics. 2011; 101(2), 449-472. 